\title{
Aerosol distribution over Europe: a model evaluation study with detailed aerosol microphysics
}

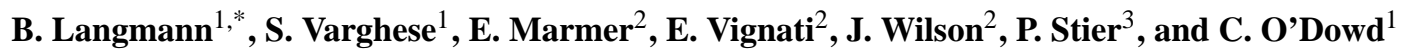 \\ ${ }^{1}$ School of Physics and Centre for Climate \& Air Pollution Studies, Environmental Change Institute, National University of \\ Ireland, Galway, Ireland \\ ${ }^{2}$ Climate Change Unit, Joint Research Centre, Ispra, Italy \\ ${ }^{3}$ Atmospheric, Oceanic and Planetary Physics, University of Oxford, Oxford, UK \\ * present affiliation: Institute of Geophysics, University Hamburg, Hamburg, Germany
}

Received: 22 November 2007 - Published in Atmos. Chem. Phys. Discuss.: 13 December 2007

Revised: 22 February 2008 - Accepted: 25 February 2008 - Published: 17 March 2008

\begin{abstract}
This paper summarizes an evaluation of model simulations with a regional scale atmospheric climatechemistry/aerosol model called REMOTE, which has been extended by a microphysical aerosol module. Model results over Europe are presented and compared with available measurements in surface air focusing on the European distribution and variability of primary and secondary aerosols. Additionally, model results obtained with detailed aerosol microphysics are compared to those based on an aerosol bulk mass approach revealing the impact of dry deposition fluxes on atmospheric burden concentration. An improved determination of elevated ozone and sulfate concentrations could be achieved by considering a diurnal cycle in the anthropogenic emission fluxes. Deviation between modelled and measured organic carbon concentrations can be mainly explained by missing formation of secondary organic aerosols and deficiencies in emission data. Changing residential heating practices in Europe, where the use of wood is no longer restricted to rural areas, need to be considered in emission inventories as well as vegetation fire emissions which present a dominant source of organic carbon.
\end{abstract}

\section{Introduction}

Tropospheric aerosols have significant effects on human health (e.g. WHO, 2002), environment (e.g. Stoddart et al., 1999) and climate (e.g. Haywood and Boucher, 2000). An improved understanding of anthropogenic and natural emission sources, secondary aerosol formation, modification of the aerosol chemical composition and size distribution is es-

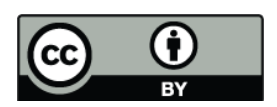

Correspondence to: B. Langmann (baerbel.langmann@zmaw.de) sential for efficient emission reduction policies to improve air quality (e.g. Solmon et al., 2006). The aerosol effects on climate due to direct and indirect aerosol radiative forcing are mainly determined by the atmospheric aerosol burden, chemical composition and size distribution (e.g. Dusek et al., 2006). Due to the relative short residence times, tropospheric aerosol undergoes considerable spatial and temporal variability with inter-annual variability strongly dependent on the prevailing meteorological conditions (e.g. Marmer and Langmann, 2007).

Until recently, three-dimensional climate models determined mainly aerosol bulk mass distributions with prescribed aerosol size distributions and mixing state (e.g. Feichter et al., 1996; Koch et al., 2006; Marmer and Langmann, 2007) with different degrees of complexity concerning oxidant availability, aqueous phase chemistry, dry and wet deposition. Major efforts have been made in recent years to improve atmospheric aerosol modeling on the global and regional scale. New efficient approaches to determine aerosol chemical composition, size distribution and microphysical interactions with a modal concept (e.g. Ackermann et al., 1998; Vignati et al., 2004) have been incorporated in climate models (e.g. Grell et al., 2005; Lauer et al., 2005; Stier et al., 2005). Sectional aerosol models used in 3-D studies (e.g. Jacobson, 2001, Gong et al., 2003) reach generally a higher accuracy compared with the modal approach (Zhang et al., 1999) but are computationally more demanding. We have chosen the modal aerosol microphysical approach of M7 (Vignati et al., 2004) to extend the regional online climate-chemistry/aerosol model REMOTE (Langmann, 2000; Marmer and Langmann, 2007). Beside the computational efficiency of the modal approach, the motivation was to develop a regional climate-chemistry/aerosol model comparable to the global ECHAM5-HAM model (Stier et al.,

Published by Copernicus Publications on behalf of the European Geosciences Union. 
Table 1. Modal structure and properties of M7. $N_{i}$ denotes the aerosol number of mode $i, M_{i}^{j}$ denotes the mass of component $j$ in mode $i$, and $r$ the dry radius.

\begin{tabular}{|c|c|c|}
\hline Modes in M7 & Soluble/Mixed & Insoluble \\
\hline $\begin{array}{l}\text { Nucleation } \\
r<0.005 \mu \mathrm{m}\end{array}$ & $\begin{array}{l}\text { Mode } 1 \\
N_{1}, M_{1}^{\mathrm{SO}_{4}}\end{array}$ & \\
\hline Aitken & Mode 2 & Mode 5 \\
\hline $0.005 \mu \mathrm{m}<r<0.05 \mu \mathrm{m}$ & $N_{2}, M_{2}^{\mathrm{SO} 4}, M_{2}^{\mathrm{BC}}, M_{2}^{\mathrm{OC}}$ & $N_{5}, M_{5}^{\mathrm{BC}}, M_{5}^{\mathrm{OC}}$ \\
\hline Accumulation & Mode 3 & Mode 6 \\
\hline $0.05 \mu \mathrm{m}<r<0.5 \mu \mathrm{m}$ & $N_{3}, M_{3}^{\mathrm{SO}_{4}}, M_{3}^{\mathrm{BC}}, M_{3}^{\mathrm{OC}}, M_{3}^{\mathrm{SS}}, M_{3}^{\mathrm{DU}}$ & $N_{6}, M_{6}^{\mathrm{DU}}$ \\
\hline Coarse & Mode 4 & Mode 7 \\
\hline $0.5 \mu \mathrm{m}<r$ & $N_{3}, M_{4}^{\mathrm{SO}_{4}}, M_{4}^{\mathrm{BC}}, M_{4}^{\mathrm{OC}}, M_{4}^{\mathrm{SS}}, M_{4}^{\mathrm{DU}}$ & $N_{7}, M_{7}^{\mathrm{DU}}$ \\
\hline
\end{tabular}

2005) to be applied for higher resolution studies over specific limited areas of interests. Here we use REMOTE to simulate European wide distributions of sulfate, sea salt, black carbon and primary organic carbon (POC) over Europe. Section 2 describes the model set-up. Model results over Europe, evaluations against available measurements and discussions are provided in Sect. 3. Section 4 provides conclusions and gives an outlook.

\section{Model set-up}

The regional three-dimensional on-line climatechemistry/aerosol model REMOTE (Regional Model with Tracer Extension, http://www.mpimet.mpg.de/en/ wissenschaft/modelle/remote.html) (Langmann, 2000; Marmer and Langmann, 2007) is one of the few regional climate models that determines the physical, photochemical and aerosol state of the model atmosphere at every model time step, thus offering the possibility to consider trace species effects on climate (e.g. Langmann, 2007). The dynamical part of the model is based on the former regional weather forecast system of the German Weather Service (Majewski, 1991). Beside the German Weather Service physical parameterisations, those of the global climate model ECHAM-4 (Roeckner et al., 1996) have been implemented in REMOTE and are used for the current study. After being released in the atmosphere, gas phase and aerosol phase species undergo transport processes (horizontal and vertical advection (Smolarkiewitz, 1983), transport in convective clouds (Tiedtke, 1989), vertical turbulent diffusion (Mellor and Yamada, 1974)) and are removed from the atmosphere by sedimentation, dry and wet deposition.

For the determination of aerosol dynamics and thermodynamics, we implemented the M7 module, which is described in detail in Vignati et al. (2004) and Stier et al. (2005), so that we only provide a brief description here. The aerosol dynamical processes in $\mathrm{M} 7$ include nucleation, coagulation and condensation. The aerosol size spectrum is represented by the superposition of seven log-normal distributions subdivided into soluble and insoluble coarse, accumulation and aitken modes and an additional soluble nucleation mode (Table 1). The five aerosol components considered in $\mathrm{M} 7$ are sulfate $\left(\mathrm{SO}_{4}\right)$, black carbon (BC), organic carbon (OC), sea salt (SS) and mineral dust (DU). These components have either negligible or low solubility or are treated as an internal mixture of insoluble and soluble compounds. Mixed particles are formed from insoluble particles by coagulation and condensation. Each mode can be described by three moments: aerosol number $N$, number median radius $r$, and standard deviation $\sigma$. Standard deviations are prescribed in M7 (Vignati et al., 2004), so that the median radius of each mode can be calculated from the corresponding aerosol number and aerosol mass, which are transported as 25 tracers (Table 1). Thus, the total number of transported trace species in REMOTE is 63 , with 38 of these participating in photochemical transformations (Langmann, 2000). Photochemical production and loss in REMOTE is determined by the RADM II chemical scheme (Stockwell et al., 1990) by 163 chemical reactions in the gas phase including a wide range of hydrocarbon degradation reactions. Photolysis rates are calculated as described by Madronich (1986) and Chang et al. (1987). Aqueous phase chemistry processes is implemented according to Walcek and Taylor (1986). Sulfate production in the aqueous phase is determined dependent on $\mathrm{pH}$ via oxidation by $\mathrm{H}_{2} \mathrm{O}_{2}, \mathrm{O}_{3}$, methylhydrogenperoxide, peroxyacetic acid and catalysed by $\mathrm{Fe}^{3+}$ and $\mathrm{Mn}^{2+}$. Cloud water $\mathrm{pH}$ is determined solving iteratively an ion balance which is continuously maintained (Walcek and Taylor, 1986). Nitrate and ammonium are not yet considered in the M7 version applied here, however, M7 is flexible to be extended to more components. Nitrate aerosols are expected to become more important in the future atmosphere due to increase in nitrate precursor emissions and the decline of $\left(\mathrm{NH}_{4}\right)_{2} \mathrm{SO}_{4}$ aerosols in wide regions of the Earth (Bauer et al., 2007).

Anthropogenic emissions of $\mathrm{SO}_{\mathrm{x}}, \mathrm{NO}_{\mathrm{x}}, \mathrm{NH}_{3}, \mathrm{CO}$, VOC's and $\mathrm{PM}_{2.5}$ obtained from the EMEP emission inventory (http://webdab.emep.int/) are prescribed as monthly fluxes 
as described in Marmer and Langmann (2007). $\mathrm{NO}_{\mathrm{x}}$ emissions are split into $\mathrm{NO}(96 \%)$ and $\mathrm{NO}_{2}(4 \%)$ emissions. Total VOC emissions are split into VOC classes according to Memmesheimer et al. (1991). For primary anthropogenic aerosol emissions, number mean radius and number concentration of the respective size mode is related to the mass concentration based on Stier et al. (2005). Chemical speciation of $\mathrm{PM}_{2.5}$ emissions into POC (primary organic carbon) and $\mathrm{BC}$ is based on Andersson-Skold and Simpson (2001). We assume $96 \%$ of $\mathrm{SO}_{\mathrm{x}}$ being released as $\mathrm{SO}_{2}$ and $4 \%$ as sulfate from which $50 \%$ are attributed to the accumulation and coarse mode, respectively. BC emissions are assumed insoluble and POC emissions soluble. Secondary organic aerosol formation is not considered in the current study. In addition to anthropogenic emissions, terrestrial biogenic terpene and isoprene emissions from forests are considered based on Guenther et al. (1991, 1993). For coarse mode sea salt, we use the same approach as described in Stier et al. (2005) with a table look-up for wind speeds between 1 and $40 \mathrm{~m} / \mathrm{s}$. The net accumulation sea-spray flux is based on Geever et al. (2005) and is used as an organic-inorganic source function for the mixture of POC and sea salt aerosols. Recent measurements at the Mace Head station at the Atlantic coast of Ireland (O'Dowd et al., 2004; Yoon et al., 2007) have shown that $\mathrm{OC}$ contributes a considerable fraction to seaspray during periods of increased biological activity of the ocean. Further details are given in O'Dowd et al. (2008). For the current application of the REMOTE model over Europe, mineral dust emissions have not been considered.

Dry deposition fluxes for gaseous compounds are determined after Wesley (1989). For aerosol particles, the same size-dependent parameterizations as in the ECHAM5-HAM model (Stier et al., 2005) are used for dry deposition and sedimentation, which are based on Ganzeveld et al. (1998) and Seinfeld and Pandis (1998). Wet deposition is computed according to Walcek and Taylor (1986) by integrating the product of the grid-averaged precipitation rate and the mean cloud water concentration which is determined from cloud base (first layer above the surface containing more than $0.001 \mathrm{~g} / \mathrm{kg}$ liquid water) to cloud top (highest level exceeding an amount of $0.001 \mathrm{~g} / \mathrm{kg}$ liquid water) for fair weather clouds and from the surface to cloud top for raining clouds. Scavenging efficiencies are based on Kasper-Giebl et al. (2000) distinguishing between soluble and insoluble aerosols dependent on cloud liquid water content. Size dependent scavenging has not been taken into account until now. In-cloud produced sulfate is distributed to the available pre-existing accumulation and coarse mode aerosol particles according to the respective number concentration (Stier et al., 2005).

REMOTE is applied with a time step of $5 \mathrm{~min}$ in $0.5^{\circ}$ horizontal resolution and 20 vertical layers of increasing thickness between the Earth's surface and the $10 \mathrm{hPa}$ pressure level using terrain following hybrid pressure-sigma coordinates. The prognostic equations are written on an ArakawaC-grid (Mesinger and Arakawa, 1976). The height of the lowest layer with prognostic trace species concentration is approximately $40 \mathrm{~m}$, dependent on surface pressure. The model domain covers Europe and the Northeast Atlantic Ocean. REMOTE is initialised at the first time step using meteorological analysis data of the European Centre for Medium Range Weather Forecast (ECMWF), which are updated at the lateral boundaries every $6 \mathrm{~h}$ and used for nudging the model in the outer 8 grid cells. Trace species concentration at the lateral boundaries are prescribed (Langmann, 2000) and held constant throughout the simulation period. Here we analyse results for January and June 2003 to take into account the seasonal variability of meteorological conditions, emissions and photochemistry. Beside the standard model simulation, four sensitivity studies have been conducted: for June 2003 a) a day-night variability has been introduced for the anthropogenic emissions, $b$ ) biogenic emissions have been increased by a factor of 5 , c) forest fire emissions have been taken into account and d) a sensitivity study with the aerosol bulk mass approach has been out carried for January and June 2003.

\section{Model evaluation and discussion}

\subsection{Meteorological conditions}

Meteorological conditions have a major influence on the distribution of the modelled atmospheric trace species and need to be evaluated carefully. Previous studies with the REMOTE model have evaluated the meteorological model simulation results against available measurements $(\mathrm{T} 2 \mathrm{~m}$, wind speed and direction, precipitation). The diurnal variability of the meteorological and chemical processes in the planetary boundary layer as well as the planetary boundary layer height and spatial variability could be reproduced by REMOTE pretty well over Europe (Langmann, 2000; Langmann and Bauer, 2002; Langmann et al., 2003). Two recent papers (Marmer and Langmann, 2007; Marmer et al., 2007) investigate the inter-annual variability of aerosol distributions over Europe by using a bulk mass approach. In Fig. 1a monthly precipitation interpolated from satellite and rain gauge measurements by GPCP (www.dwd.de/en/FundE/ $\mathrm{Klima} / \mathrm{KLIS} / \mathrm{int} / \mathrm{GPCC} /$ ) is shown in $2.5^{\circ}$ for comparison with REMOTE model results in $0.5^{\circ}$ (Fig. 1b) for approximately the same area. The REMOTE model is able to reproduce the measured precipitation magnitude, spatial pattern and seasonality over Europe and the Atlantic Ocean. Note that close to the western lateral model boundary where the major inflow occurs, simulated precipitation is underestimated. The reason is the missing information about liquid water content in the ECMWF analysis data, which serve as lateral boundary information. The prevailing dry conditions during summer 2003 (e.g. Hodzic et al., 2007) are visible in particular over Southern Europe. The REMOTE model is also able to reasonably determine precipitation measured 
January 2003

(a)

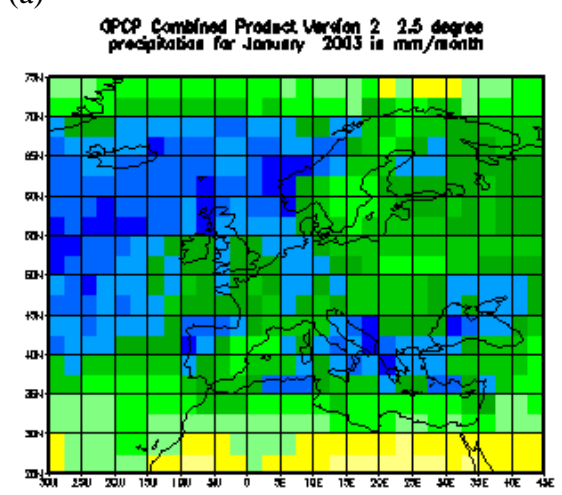

(b)

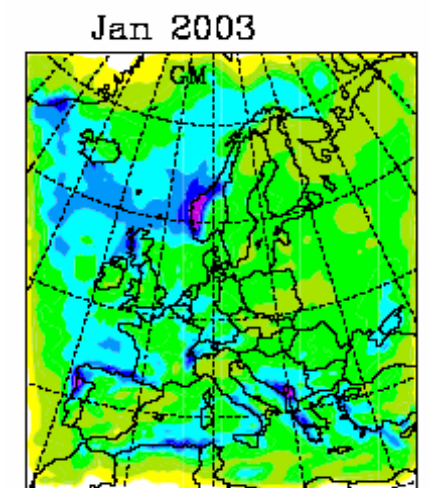

June 2003
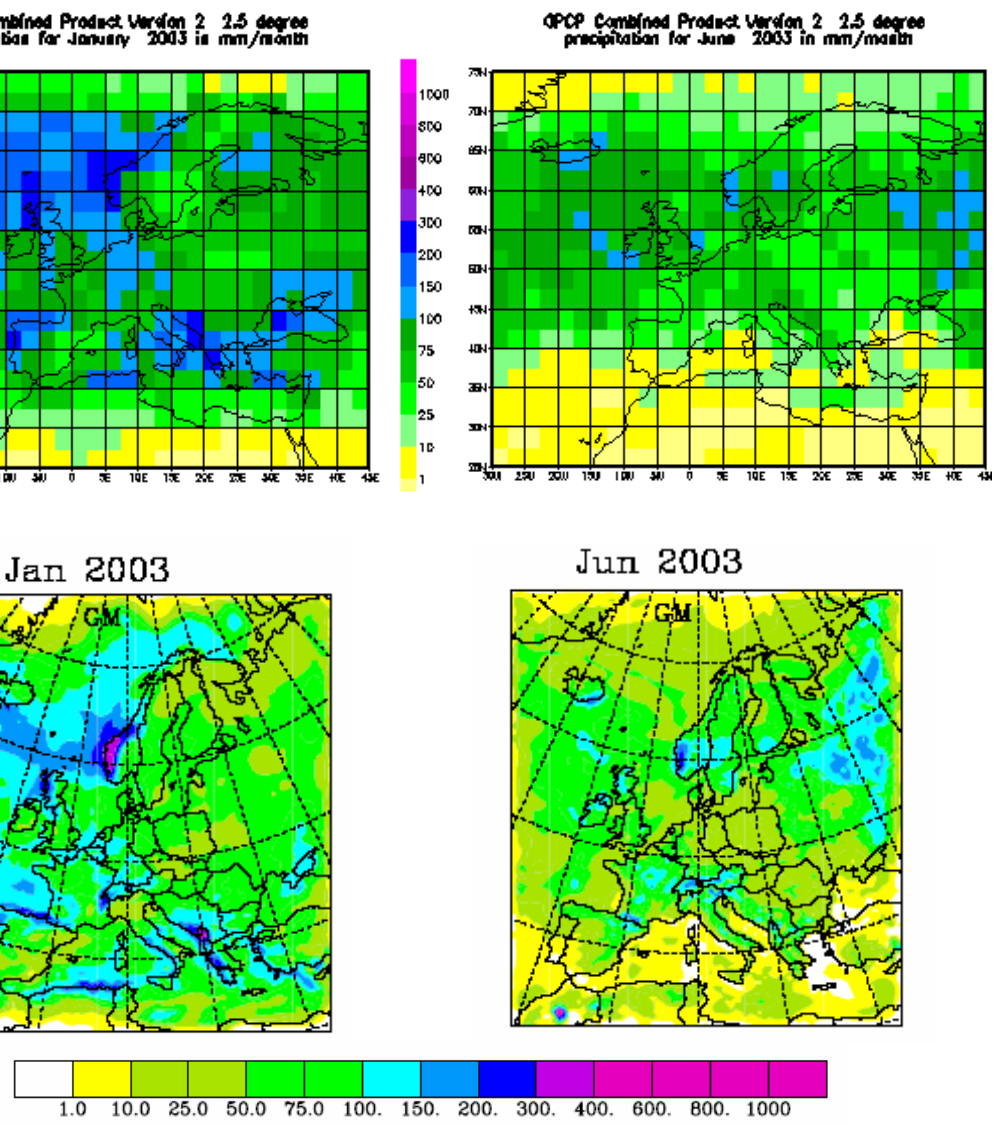

(c)

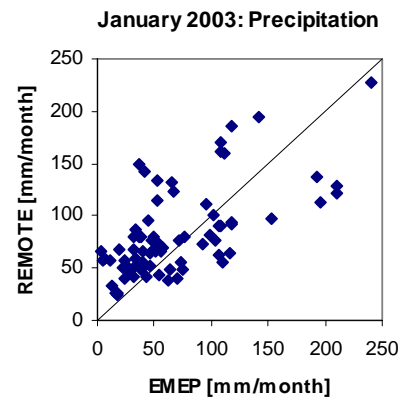

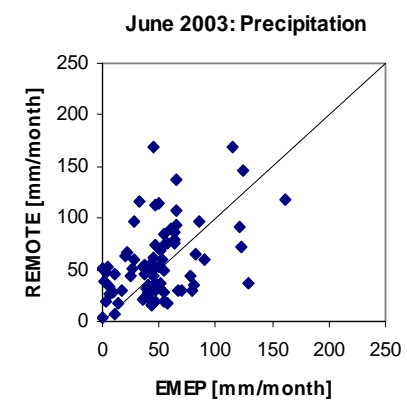

Fig. 1. (a) Measured and (b) simulated precipitation by REMOTE during January and June 2003 in $\mathrm{mm} / \mathrm{month}$. (c) REMOTE monthly precipitation at EMEP stations against EMEP measurements.

at stations from the EMEP network (http://www.nilu.no/ projects/ccc/emepdata.html), which are located on land areas only (Fig. 1c). Measured and simulated wind speed and direction at the Mace Head observation station $\left(53.1^{\circ} \mathrm{N}\right.$, $9.3^{\circ} \mathrm{W}$ ) at the Atlantic coast of Ireland are presented in Fig. 2 and show nearly perfect agreement. This is not astonishing as it is not that demanding for the model to reproduce the wind components at a coastal site close to its western and major inflow boundary. (For further Mace Head data see Fig. 6). Slightly lower simulated wind speeds are due to the model resolution of $0.5^{\circ}$ and a land fraction of approximately 50\% in the grid box where the Mace Head site is located, inducing more surface friction than over open ocean areas. In the beginning of January 2003, a blocking situation with easterly winds occurred whereas westerly winds prevail during June 2003. During January significantly higher wind speeds were reached compared to June. 
January 2003
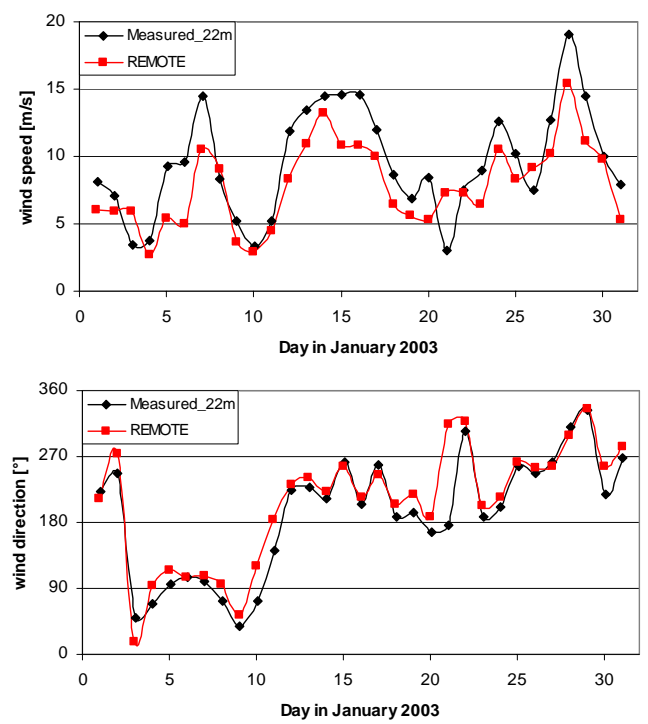

June 2003
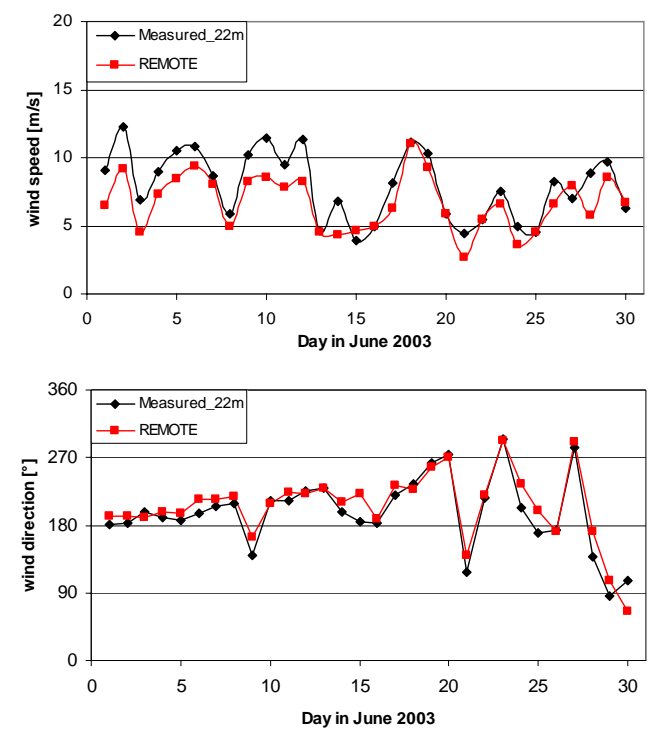

Fig. 2. Measured and modeled wind speed and direction at Mace Head (53.1 $\left.{ }^{\circ} \mathrm{N}, 9.3^{\circ} \mathrm{W}\right)$ during January and June 2003 . Model results out of the first layer in approximately $30 \mathrm{~m}$ height are shown.

Table 2. European monthly mean burden, lifetime and sinks.

\begin{tabular}{|c|c|c|c|c|c|c|}
\hline Species & Month 2003 & $\begin{array}{l}\text { Atmospheric } \\
\text { burden } \\
{\left[\mathrm{mg} / \mathrm{m}^{2}\right]}\end{array}$ & $\begin{array}{l}\text { Lifetime } \\
\text { [days] }\end{array}$ & $\begin{array}{l}\text { Wet } \\
\text { deposition } \\
{\left[\mathrm{mg} / \mathrm{m}^{2} / \mathrm{month}\right]} \\
{[\%]}\end{array}$ & $\begin{array}{l}\text { Dry } \\
\text { deposition } \\
{\left[\mathrm{mg} / \mathrm{m}^{2} / \mathrm{month}\right]} \\
{[\%]}\end{array}$ & $\begin{array}{l}\text { Sedimentation } \\
{\left[\mathrm{mg} / \mathrm{m}^{2} / \text { month }\right]} \\
{[\%]}\end{array}$ \\
\hline \multirow[t]{4}{*}{ Sea salt } & Jan & 7.9 & 0.15 & 1201.9 & 262.9 & 129.6 \\
\hline & & & & 75.4 & 16.5 & 8.1 \\
\hline & Jun & 4.4 & 0.47 & 147 & 24.2 & 108.4 \\
\hline & & & & 52.6 & 8.6 & 38.8 \\
\hline \multirow[t]{4}{*}{ POC } & Jan & 0.17 & 0.71 & 7.1 & 0.28 & 0.013 \\
\hline & & & & 96 & 3.8 & 0.2 \\
\hline & Jun & 0.36 & 1.5 & 6.9 & 0.43 & 0.058 \\
\hline & & & & 93.4 & 5.8 & 0.8 \\
\hline \multirow[t]{4}{*}{ Sulfate } & Jan & 0.87 & 0.38 & 68 & 0.87 & 1 \\
\hline & & & & 97.3 & 1.3 & 1.4 \\
\hline & Jun & 2.3 & 1.9 & 34.4 & 0.91 & 0.8 \\
\hline & & & & 95.3 & 2.5 & 2.2 \\
\hline \multirow[t]{4}{*}{$\mathrm{BC}$} & Jan & 0.087 & 0.98 & 2.6 & 0.15 & 0.003 \\
\hline & & & & 94.6 & 5.3 & 0.1 \\
\hline & Jun & 0.15 & 2.9 & 1.4 & 0.11 & 0.003 \\
\hline & & & & 92.2 & 7.6 & 0.2 \\
\hline
\end{tabular}

\subsection{Atmospheric burden and lifetime}

Atmospheric column burden, lifetime and percentage contribution of the three removal processes (wet deposition, dry deposition and sedimentation) are given in Table 2 for January and June 2003, respectively. A pronounced seasonal variability is determined with considerably shorter life times during winter with lower column burden for sulfate, BC and OC accompanied by more removal than during summer. Only the winter atmospheric burden of sea salt exceeds the summer burden, while more removal leads to a shorter lifetime than during summer. Compared with the global annual mean lifetimes of aerosols (e.g. Stier et al., 2005), aerosol lifetimes over Europe during summer are about half. However, 
(a)

January 2003

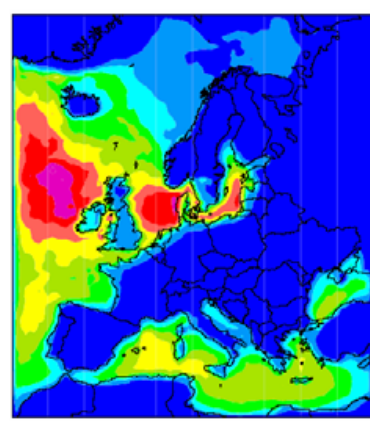

June 2003

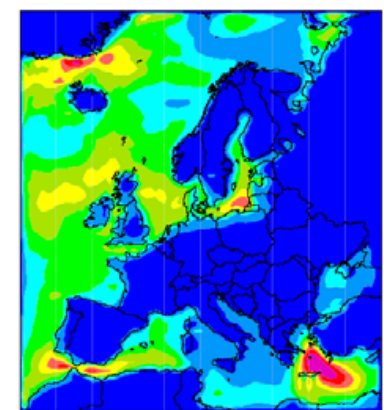

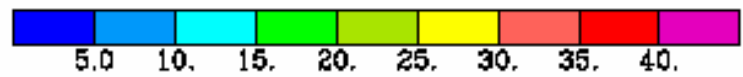

(b)

wd Cl- [m g/m 2/month] Jan 2003138
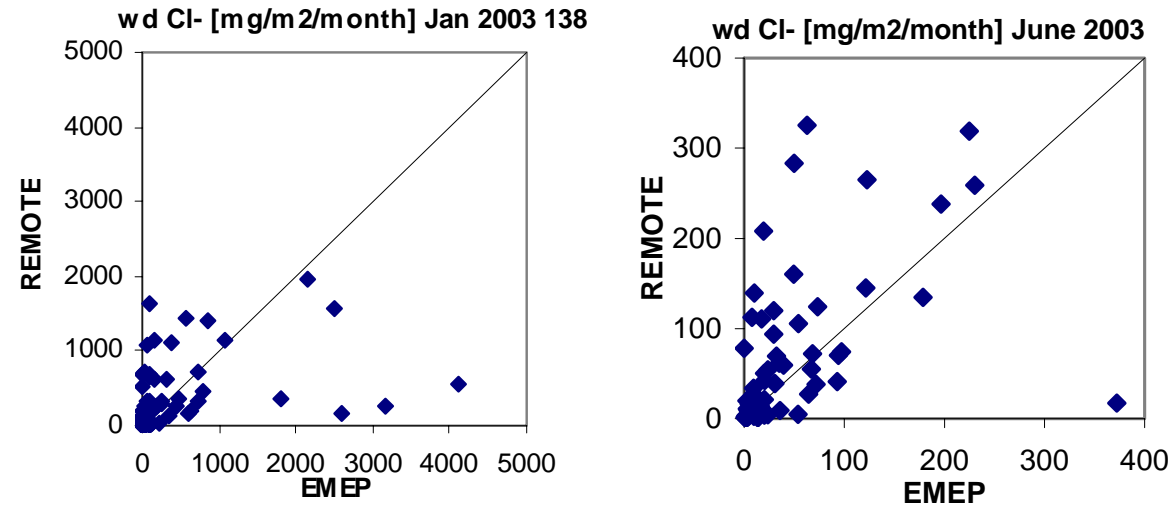

Fig. 3. Sea salt: (a) REMOTE modeled sum of near surface coarse and accumulation mode sea salt in $\mu \mathrm{g} / \mathrm{m}^{3}$ during January and June 2003 . (b) REMOTE monthly wet depositions of chloride at EMEP stations against EMEP measurements in $\mathrm{mg} / \mathrm{m}^{2} / \mathrm{month}$ with different intervals for January and June 2003 (measured [mg/l] is converted to $\left[\mathrm{mg} / \mathrm{m}^{2} / \mathrm{month}\right.$ ] by multiplication with measured precipitation in [mm/month]).

European mean conditions cannot be directly compared with globally averaged data where over $70 \%$ of the total area is made up of ocean and with prominent contributions of the tropical regions. Note that transport across the lateral boundaries is another removal / source process for limited area models which has not been taken into account here.

\subsection{Sea salt}

The spatial distribution of modelled sea salt in surface air is illustrated in Fig. 3a as the sum of accumulation and coarse mode sea salt, with the accumulation mode contributing about $10 \%$. During January 2003, the highest sea salt concentrations occur over the Northeast Atlantic, west of Ireland and Scotland, the North Sea and the Baltic Sea. During June 2003, elevated sea salt concentrations are found over the Mediterranean Sea, nearby Greenland and over the Baltic Sea. Transport of sea salt from the ocean to continental areas is relatively small but coastal areas are affected considerably. Wet deposition of chloride (Fig. 3b) is approximately one order of magnitude higher in January compared to June 2003. The REMOTE model fairly well reproduces this seasonal variability as well as the variability from low deposition fluxes at inland EMEP sites to the higher ones at the coastal sites. Elevated wet deposition fluxes of $\mathrm{NaCl}$ in the Alpine region occur during the winter season because of the use of salt for melting snow on the roads. This source of $\mathrm{NaCl}$ is not considered in the model. At the few Norwegian and Danish EMEP sites where sodium and/or chloride aerosol concentrations in surface air are measured, the REMOTE model overestimates the measured concentrations by a factor of 2-6. It should be emphasized again that this is caused mainly by the coarse mode sea salt particles.

\subsection{Sulfur species}

In Fig. 4, modelled and measured concentration of $\mathrm{SO}_{2}$ and sulfate and the wet deposition fluxes of sulfate are compared. For modelled sulfate, the contribution of all size modes are considered with the accumulation mode containing the major 
(a)

January 2003

\section{SO2 [ugS/m3] Jan 2003 RUN138}

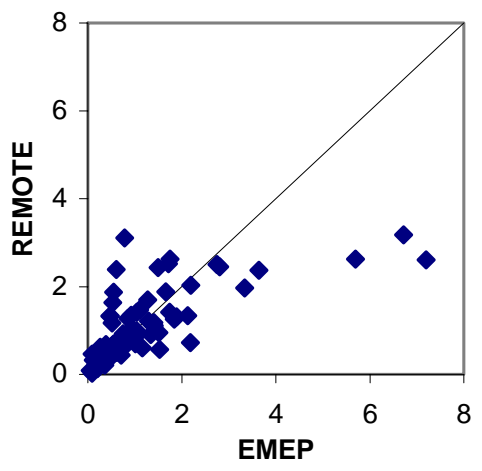

(b)

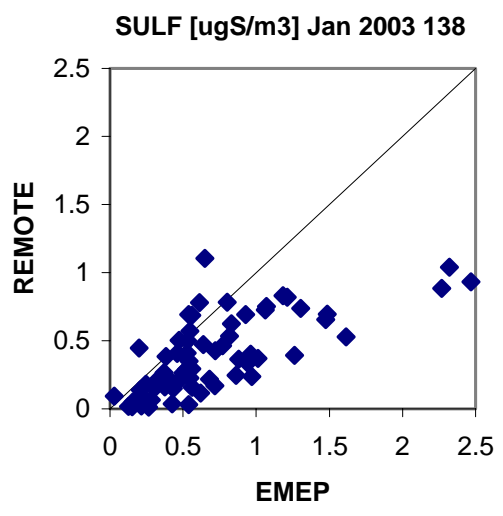

(c)

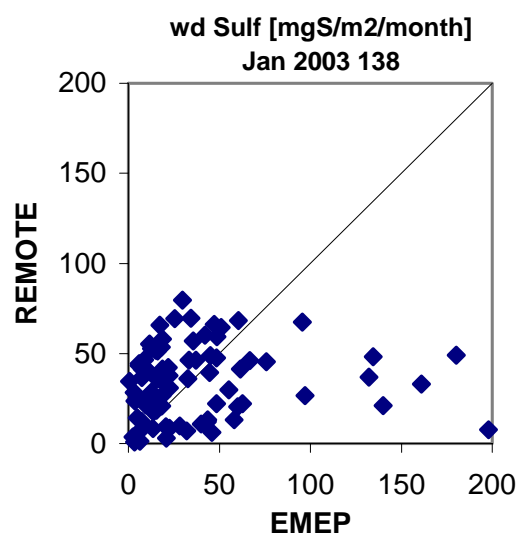

June 2003

SO2 [ugS/m3] June 2003 RUN138

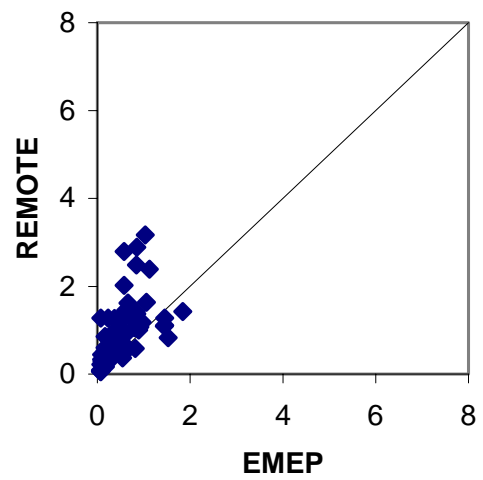

Sulf [ugS/m3] June2003 RUN138

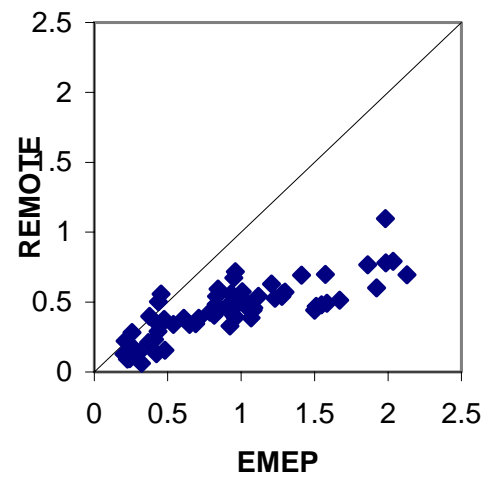

wd Sulf [mgS/m2/month] June 2003 RUN138

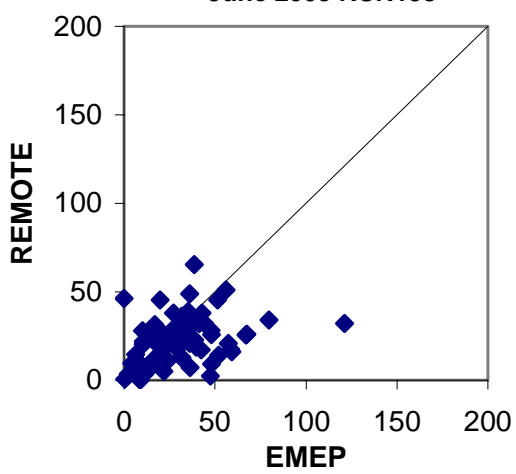

Fig. 4. Sulfur species: REMOTE monthly concentration of (a) $\mathrm{SO}_{2}$ and (b) Sulfate in $\left[\mu \mathrm{gS} / \mathrm{m}^{3}\right]$, and (c) sulfate wet deposition in $\left[\mathrm{mgS} / \mathrm{m}^{2} / \mathrm{month}\right]$ at EMEP stations compared against EMEP measurements.

amount of mass. In January, only the elevated $\mathrm{SO}_{2}$ concentrations are underestimated by the REMOTE, whereas during June a principle overestimation is found. Simulated sulfate is underestimated during both seasons, in particular the elevated concentrations. As the wet deposition fluxes of sulfate are reasonably reproduced by REMOTE and enough $\mathrm{SO}_{2}$ is available, sulfate formation in particular during the summer season is supposed to be oxidant limited. To analyse this dependency, we compare modelled and measured concentrations of photo-oxidants. 
January 2003

(a)

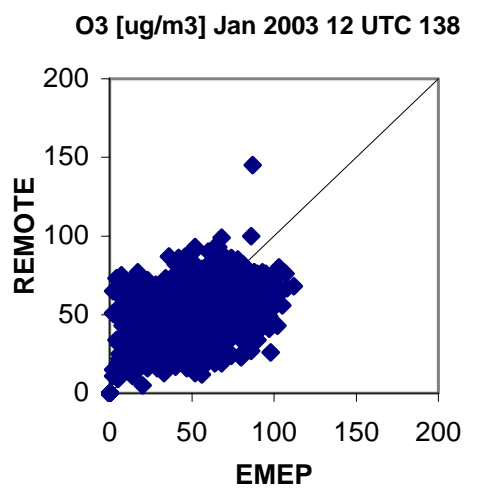

(b)

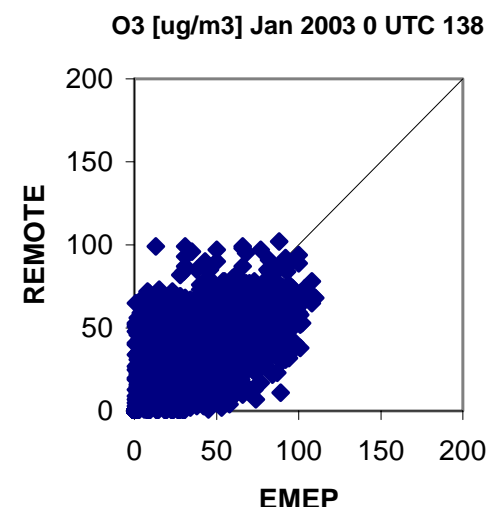

(c)

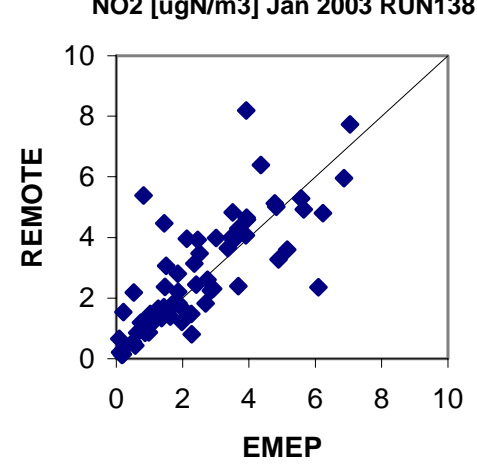

June 2003
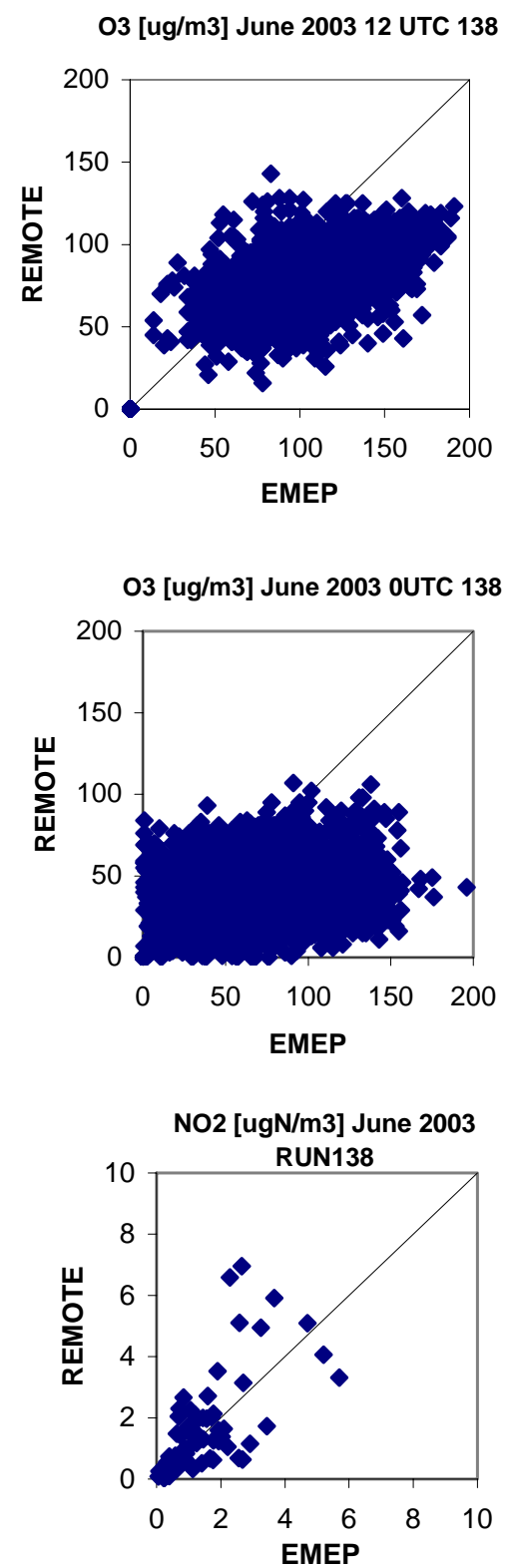

Fig. 5. Photo-oxidants: REMOTE daily concentrations of ozone (a) at noon and (b) at midnight in $\left[\mu \mathrm{g} / \mathrm{m}^{3}\right]$ and (c) monthly concentration of $\mathrm{NO}_{2}$ in $\left[\mu \mathrm{gN} / \mathrm{m}^{3}\right]$ at EMEP stations compared against EMEP measurements.

\subsection{Photo-oxidants}

Daily noon and midnight ozone concentrations reflect the pronounced diurnal cycle of ozone which is captured well by the REMOTE model simulation (Fig. 5a, b). The modelled ozone concentrations during January are in good agreement with the measured ones. During June, the elevated $\mathrm{O}_{3}$ concentrations are underestimated by the model. Modelled
$\mathrm{NO}_{2}$ concentrations agree reasonably well with the measurements at the EMEP sites (Fig. 5c). Either the availability of VOC limits $\mathrm{O}_{3}$ and sulfate production during summer or photolysis of $\mathrm{NO}_{2}$ is underestimated resulting in an insufficient catalysis of the $\mathrm{NO} / \mathrm{NO}_{2}$ cycle accompanied by lower photo-oxidant formation. The use of monthly emission data without diurnal variability offers one explanation for the underprediction of elevated ozone concentration during 
(a)

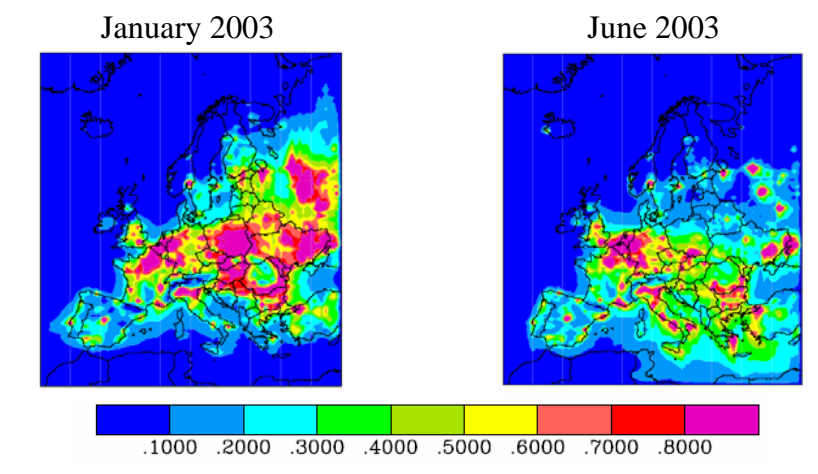

(b)

BC [ug/m3] Jan 2003 RUN138

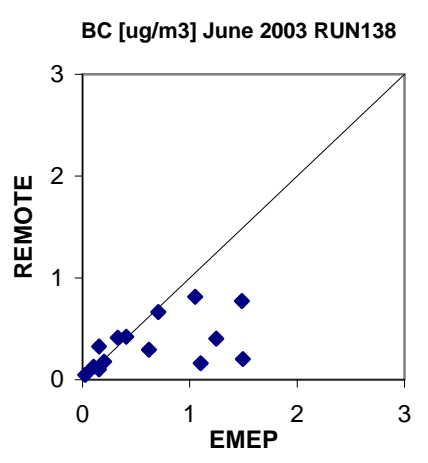

(c)
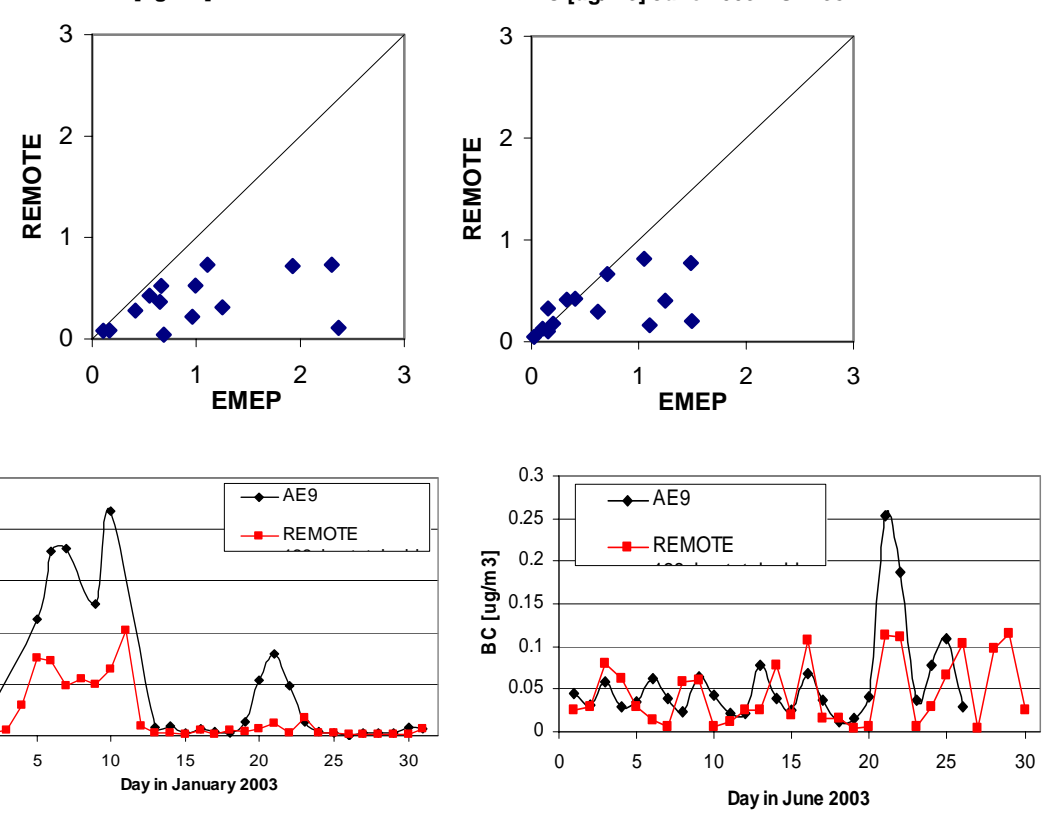

Fig. 6. BC: (a) REMOTE modeled total BC concentration in $\mu \mathrm{g} / \mathrm{m}^{3}$ in surface air during January and June 2003. (b) REMOTE monthly $\mathrm{BC}$ concentration at EMEP stations against EMEP measurements in $\mu \mathrm{g} / \mathrm{m}^{3}$. (c) Time series of modeled (in red) and measured (in black) BC concentrations at Mace Head.

summer. In a sensitivity study, a simple diurnal variability was included by scaling emissions from 07:00-18:00 UTC by a factor of 1.5 and those from 19:00-06:00 UTC by 0.5 , respectively. The resulting ozone concentrations in surface air at noon during June 2003 are modified by $\max \pm 5 \%$ at the EMEP locations, whereas near surface sulfate concentrations are systematically increased at all EMEP stations by $5-12 \%$. These results emphasize that the diurnal variability of anthropogenic emission fluxes should be considered to reproduce measured photo-oxidants concentrations and the oxidation capacity of the troposphere more realistically. Another sensitivity study for June 2003 investigates the impact of biogenic VOC emissions. Due to the considerable uncertainty (e.g. Simpson et al., 1999) biogenic VOC emissions have been increased by a factor of 5 . At noon, near surface ozone concentrations are mainly increased, at several EMEP stations more than $20 \%$. However, near surface sulfate con- centrations are slightly reduced indicating that under these conditions photo-oxidation formation becomes $\mathrm{NO}_{\mathrm{x}}$ limited. Another possible explanation is that lateral boundary concentrations are held constant throughout the simulation. By applying a global to mesoscale model chain, Langmann et al. (2003) showed for ozone concentration that the global model dominates the nested higher resolution model results increasingly with height. In addition, convective events couple free troposphere and PBL air masses so that ozone from above is injected into the PBL contributing an amount of 5$10 \mathrm{ppbv}$ to near-surface ozone in the afternoon hours. The impact of vegetation fire emissions is discussed in the following subsection. 
(a)

(b)
January 2003

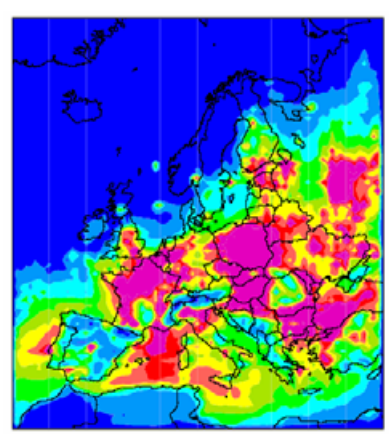

June 2003

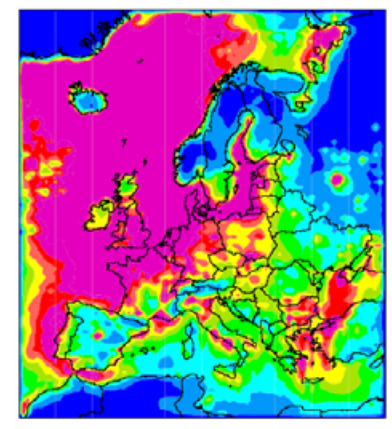

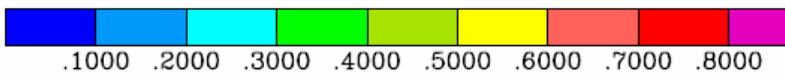

OC [ug/m 3] June 2003 RUN138

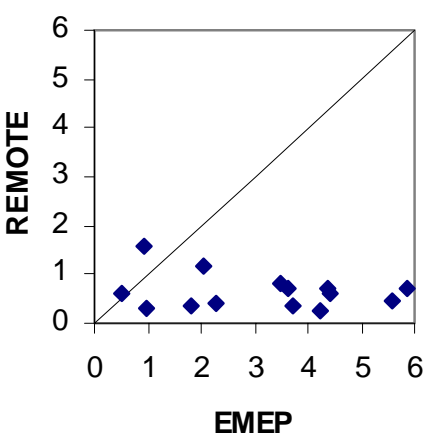

Fig. 7. POC: (a) REMOTE modeled total POC concentration in $\mu \mathrm{g} / \mathrm{m}^{3}$ in surface air during January and June 2003. (b) REMOTE monthly POC concentration at EMEP stations against EMEP measurements in $\mu \mathrm{g} / \mathrm{m}^{3}$. Note that for January the $\mathrm{y}$ and $\mathrm{x}$-axis are different.

\subsection{Carbonaceous aerosols}

BC concentrations in surface air show a pronounced seasonal variability (Fig. 6a). During winter, higher concentrations occur over Eastern Europe due to domestic heating and accumulation under high pressure conditions in the planetary boundary layer (PBL). In the Mediterranean area accumulation takes place during summer. Measured concentrations of BC exceeding $0.5 \mu \mathrm{g} / \mathrm{m}^{3}$ are underestimated by the REMOTE model by a factor of about 2 (Fig. 6b). Comparison with observations at Mace Head (Fig. 6c) indicate that REMOTE can reproduce the large scale transport of BC from continental Europe towards Mace Head in particular during the beginning of January 2003 under the influence of a high pressure system and easterly winds (Fig. 2). However, elevated BC concentrations at Mace Head are also underpredicted by REMOTE.

REMOTE model results of near surface POC distributions over Europe during January and June 2003 show significant differences over both, the continent and the ocean (Fig. 7). During winter the highest concentrations are determined over Eastern Europe due to domestic heating. Even higher POC concentrations are found during summer in the marine boundary layer where POC is released together with sea salt - both in the accumulation mode - dependent on wind speed (O'Dowd et al., 2008). This source of POC has not been taken into account before. It offers however one possible explanation for the missing source of OC, e.g. during the ACE-Asia campaign (Heald et al., 2005), where numerical modelling could not reproduce measured OC concentrations. Transport of marine POC from the ocean to continental areas is found to be relatively small but coastal areas are affected considerably. At Mace Head, $0.53 \mu \mathrm{g} / \mathrm{m}^{3} \mathrm{OC}$ is measured (Yttri et al., 2007) during June 2003 and $0.62 \mu / \mathrm{mg}^{3} \mathrm{OC}$ is determined by REMOTE, from which $0.55 \mu \mathrm{g} / \mathrm{m}^{3}$ OC originates from the ocean. Comparisons at the other measurements sites participating in the EMEP EC/OC campaign (Yttri et al., 2007) reveal significant deviations between measured and modelled OC concentration. During winter, modelled concentrations are systematically underpredicted by a factor of 10 whereas during summer no systematic connection between measured and modelled OC concentrations can be found.

Until today, modelling of carbonaceous aerosols remains a challenge due to the uncertainties of the various primary and secondary sources. Within the EU project CARBOSOL, a 
(a) Winter: source contribution to OC in \%

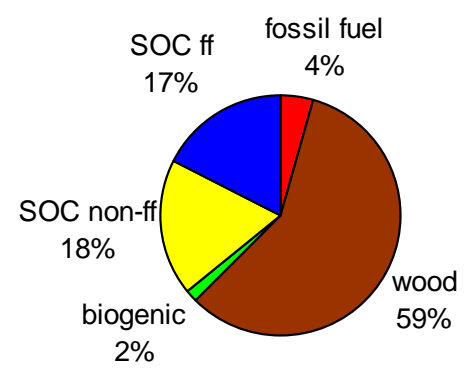

(b)

\section{Summer: source contribution to $\mathrm{OC}$ in $\%$}

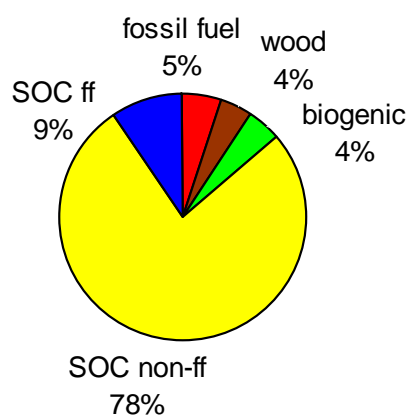

Fig. 8. Averaged results of the source apportionment analysis of measured carbonaceous aerosols at five locations in Europe (Gelencser et al., 2007) during (a) winter and (b) summer. (ff: fossil fuel, non-ff: non-fossil fuel).

source apportionment analysis (Gelencser et al., 2007) of carbonaceous $\mathrm{PM}_{2.5}$ aerosols has been carried out along a transect of five locations from the Azores to Hungary. The analysis distinguishes between carbonaceous aerosols from fossil fuel combustion and from biomass burning as well as primary and secondary organic carbon (SOC). Sampled BC and POC at the five CARBOSOL stations appointed to fossil fuel combustion is found to be in good agreement with REMOTE model results obtained with a bulk aerosol mass approach (Marmer and Langmann, 2007): during winter a mean value of $0.36 \mu \mathrm{g}(\mathrm{C}) / \mathrm{m}^{3} \mathrm{BC}\left(0.21 \mu \mathrm{g}(\mathrm{C}) / \mathrm{m}^{3} \mathrm{OC}\right)$ has been measured compared to $0.30 \mu \mathrm{g}(\mathrm{C}) / \mathrm{m}^{3} \mathrm{BC}\left(0.24 \mu \mathrm{g}(\mathrm{C}) / \mathrm{m}^{3} \mathrm{OC}\right)$ as model result; during summer the mean measured value is $0.32 \mu \mathrm{g}(\mathrm{C}) / \mathrm{m}^{3} \mathrm{BC}\left(0.19 \mu \mathrm{g}(\mathrm{C}) / \mathrm{m}^{3} \mathrm{OC}\right)$ compared to a mean modelled value of $0.23 \mu \mathrm{g}(\mathrm{C}) / \mathrm{m}^{3} \mathrm{BC}\left(0.14 \mu \mathrm{g}(\mathrm{C}) / \mathrm{m}^{3} \mathrm{OC}\right)$. POC from wood burning is found to contribute almost $90 \%$ to the total POC in Aveiro and K-Puszta during winter, and approximately $50 \%$ at the other sites during winter and summer (Fig. 8). The surprisingly high contribution of modern carbon burning during winter has also been found by Szidat et al. (2007) who observed an overwhelming impact of carbonaceous aerosols from residential wood burning on particulate matter in Alpine valleys during winter-time. Until now, only little attention has been paid to residential wood burning because it was assumed to contribute only marginal to the total energy consumption in industrialized Europe. Due to rising fuel prices and the climate change discussion, residential heating is switching from fossil gas and oil burning to wood burning in fireplaces and modern pellet heaters in some European countries, while in others peat burning makes an important contribution to the total energy consumption. Updated emission inventories need to take into account the changing heating practices in Europe and the use of wood burning not only in rural but also in urban areas.

During summer, very high contributions of SOC (more than 70\%) from non-fossil sources were found in the CARBOSOL samples (Fig. 8) which include SOC from biogenic emissions from vegetation as well as from vegetation fires. Since we did not yet consider secondary organic aerosol formation in the REMOTE/M7 model, the missing SOC explains the modelled underprediction during summer as well as the missing correlation between modelled and measured data. It is however important to mention that the concept of SOC by Gelencer et al. (2007) also includes directly emitted semi-volatile organic compounds at low temperatures, which make a major contribution to observed SOC during winter. In the model, this type of $\mathrm{OC}$ aerosol is considered to be primary and its emissions are prescribed by the EMEP emission inventory.

The impact of vegetation fire emissions on the REMOTE results has been analyzed in another sensitivity study for June 2003. In this experiment, we make use of the Global Fire Emissions Database, Version 2 available from http://ess1.ess. uci.edu/ jranders/data/GFED2/ (van der Werf et al., 2006). During June 2003, vegetation fires contributed $0.4 \% \mathrm{NO}_{\mathrm{x}}$, $0.8 \% \mathrm{VOC}, 4.6 \% \mathrm{CO}, 2.0 \% \mathrm{BC}$ and $27.0 \% \mathrm{POC}$ to the total emissions according to the GFED2 and the EMEP emission inventory. During August 2003, when severe wild fires occurred mainly in Portugal, Italy and the Balkan, the POC contribution from wild fires exceeded even $60 \%$. The high POC contribution is in agreement with Novakov et al. (1997) who report that $\mathrm{PM}_{2.5}$ aerosols from wild fires are made up mainly of OC with only 4-25\% BC (dependent on the burning conditions) and an even smaller contribution from inorganic species. Hodzic et al. (2007) who did not distinguish between BC and OC estimated that during summer 2003 (August 2003) wild fires in Europe contributed an equivalent of $48 \%(84 \%)$ of the total $\mathrm{PM}_{2.5}$ anthropogenic emissions. Tsyro et al. (2007) reported that considering vegetation fire emissions over Europe during summer 2002 and 2003 reduced the EMEP model underestimation of BC by 4-15\% and improved the temporal correlation at most sites affected by fire emissions. Considering the small contribution of $\mathrm{BC}$ released from vegetation fires and the cumulative 
(a)

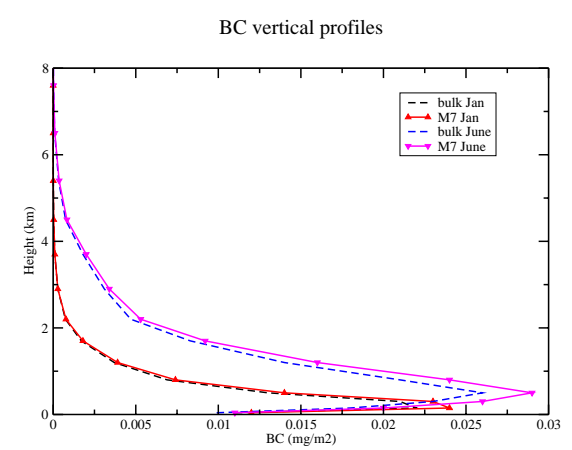

(b)

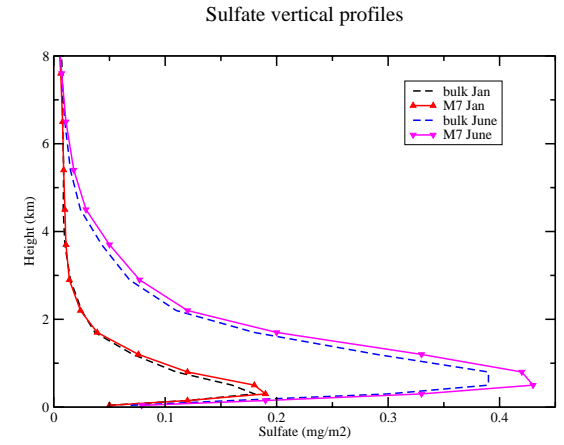

Fig. 9. European mean vertical distribution of (a) BC and (b) sulfate in $\mathrm{mg} / \mathrm{m}^{2}$ during January and June 2003 as determined by REMOTE/M7 and the bulk mass approach.

fire intensity at only few locations not necessarily close to the measurement locations, it is understandable that wild fire emissions do not contribute much to the atmospheric BC concentrations. The sensitivity study carried out here for June 2003 shows the highest impact of vegetation fires at the EMEP site Braganca in Portugal, where modelled monthly mean $\mathrm{BC}$ concentrations increased by a factor of 1.4 , POC by a factor 2.8 , followed by Ispra, Italy (BC*1.1, POC*1.5), Illmitz, Austria (POC*1.4) and Aspvreten, Sweden (POC*1.3). In contrast to Tsyro et al. (2007) and Hodzic et al. (2007) who distributed fire emissions between model vertical layers dependent on fire buoyancy, we released the fire emissions into the first model layer so that the local impact close to the fires is most probably too high and the long range transport too small. Despite this simplification, the sensitivity study shows the considerably higher impact of POC emissions from fires on atmospheric OC concentration compared to $\mathrm{BC}$ concentrations. It also reveals that taking vegetation fires into account alone does not solve the general underestimation of modelled atmospheric OC: at Braganca, Portugal vegetation fire emissions increased modelled OC concentrations from $0.25 \mu \mathrm{g} / \mathrm{m}^{3}$ to $0.71 \mu \mathrm{g} / \mathrm{m}^{3}$, but $4.2 \mu \mathrm{g} / \mathrm{m}^{3}$ has been measured. The overwhelming contribution of SOC to the total atmospheric OC concentration according to the measurements at CARBOSOL sites (Gelencer et al., 2007) is the most likely explanation.

\section{Bulk aerosol mass approach versus aerosol micro- physics}

In this section we compare model results from simulations with the REMOTE model extended by M7 with those obtained with the previously used bulk aerosol mass approach (Marmer and Langmann, 2007). In this previous version of REMOTE, we described sulfate and carbonaceous aerosol species only by considering their mass concentration and prescribed aerosol size distribution and mixing state. The two model versions also differ in their parameterisation of dry deposition and sedimentation. The bulk mass approach uses a combined dry deposition and sedimentation velocity for a prescribed size distribution of sulfate aerosols (Walcek et al., 1986) which is applied also for BC and POC. In REMOTE/M7, dry deposition and sedimentation is dependent on the aerosol size distribution (see Sect. 2). Size dependent scavenging has not been taken into account in REMOTE/M7 until now. Both model simulations have been carried out using ECMWF meteorological analysis data and identical chemical data at the lateral boundaries as described in Sect. 2. EMEP emissions data are also identical, however, sea salt emissions and marine POC emissions are not considered when using the aerosol bulk mass approach. Therefore we focus our attention on $\mathrm{BC}$ and sulfate.

Modelled European vertical profiles for $\mathrm{BC}$ and sulfate determined by REMOTE/M7 and the bulk mass approach are shown in Fig. 9 revealing a pronounced seasonal variability with higher aerosol burden in the entire PBL and the lower free troposphere during summer. REMOTE/M7 determines a higher peak aerosol burden and small increase above this peak compared with the bulk mass approach. During June 2003, REMOTE/M7 determines for BC and sulfate 10\% higher European column concentrations and nearly 5\% less removal for $\mathrm{BC}$ ( $12 \%$ more for sulfate) by wet deposition, dry deposition and sedimentation (Fig. 10). Increased transport across the Mediterranean Sea compared with simulation results obtained with the aerosol bulk mass approach occurs for $\mathrm{BC}$ whereas accumulation over the Mediterranean area is nearly identical for sulfate, but over the Northern Atlantic and North-eastern Europe higher column concentrations of sulfate are visible. January 2003 simulation results with REMOTE/M7 differ from those obtained with the aerosol bulk mass approach by nearly $10 \%$ increase in column concentration for BC (5\% increase in sulfate), but a factor of 1.6 increase in wet deposition, dry deposition and sedimentation for BC and sulfate. We find considerable higher wet deposition fluxes with REMOTE/M7 compared with the aerosol 


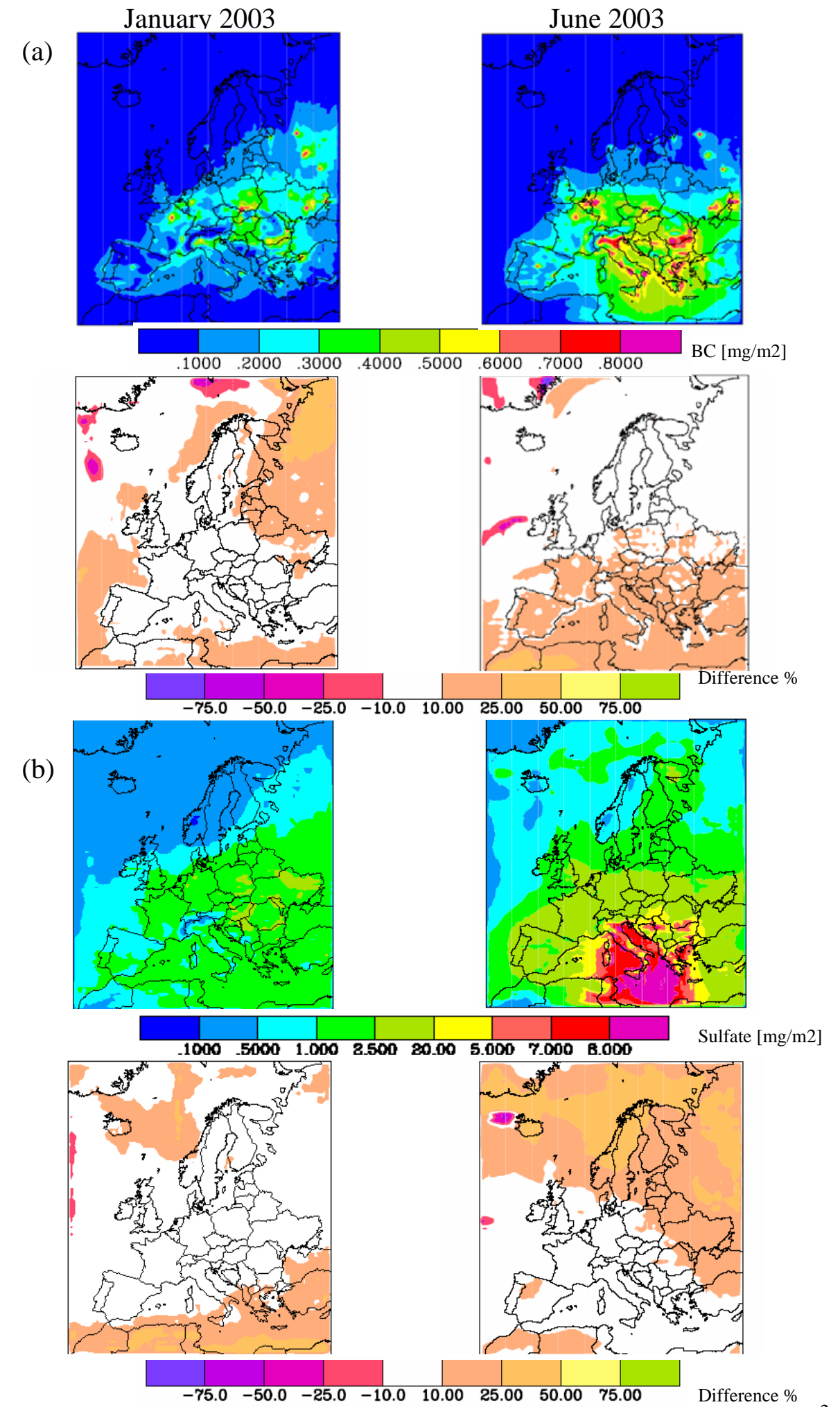

Fig. 10. Column concentration of (a) BC and (b) sulfate in $\mathrm{mg} / \mathrm{m}^{2}$ during January and June 2003 and percentage difference between detailed aerosol microphysics and aerosol mass bulk approach. 
bulk mass approach (January: factor 1.8; June: factor 1.2), but lower dry deposition fluxes (January: factor 0.6; June: factor 0.3 ) for BC as well as for sulfate. Even though dry deposition and sedimentation fluxes are small compared with wet deposition fluxes (Table 2), the combined sedimentation and dry deposition velocity of Walcek et al. (1986) can be assumed to overestimate these removal fluxes. As dry deposition is a considerable loss process close to the sources before dilution and transport to higher atmospheric levels takes place, higher dry deposition fluxes are consequently associated with decreased long-range transport (Fig. 10) and can explain the differences in model simulation results with REMOTE/M7 and the bulk mass approach. Figure 10 also reveals the differences in transport of $\mathrm{BC}$ and sulfate resulting from the differences of release and formation processes for insoluble BC and soluble sulfate.

In summary, the non-linear development of atmospheric concentration dependent on transport, chemical and microphysical transformation triggered by different removal fluxes are responsible for the differences between REMOTE/M7 and the bulk aerosol mass approach model results. Principally, the percentage contribution of the individual removal processes agrees better with literature values for REMOTE/M7 (see Sect. 3.2) than for the bulk mass approach. As dry deposition and sedimentation flux measurements are hardly available, a further evaluation is beyond the scope of this manuscript.

\section{Conclusions and outlook}

The REMOTE model (Langmann, 2000) extended by the aerosol modal microphysics (Vignati et al., 2004) is able to reasonably reproduce measured meteorological and trace species quantities over Europe, e.g. precipitation, the amount and variability of wet deposition fluxes of sea salt and sulfate, and trace species concentration in surface air. There are numerous simplifications and sources of uncertainty related to this kind of climate-chemistry/aerosol modelling. Even though we compared only trace species measurements in surface air in addition to wet deposition fluxes, we conclude that the major deviation between modelled and measured concentrations can be explained by deficiencies in used emission data and missing formation of secondary organic aerosols. The following conclusions have been drawn:

- The diurnal variability of anthropogenic emission fluxes should be considered to reproduce measured photooxidants concentrations and the oxidation capacity of the troposphere more realistically e.g. by scaling anthropogenic emissions according to the diurnal cycle of traffic volume (e.g. Memmesheimer et al., 1991). REMOTE model results, in particular regarding elevated ozone and sulfate concentrations in near surface air during summer, are shown to benefit from a simple diurnal cycle introduced to the emission fluxes.
- Measured BC and POC concentrations attributed to fossil fuel combustion (Gelencser et al., 2007) have been found to be in good agreement with REMOTE model results (Marmer and Langmann, 2007). However, total $\mathrm{BC}$ and $\mathrm{OC}$ aerosol concentration are underestimated by REMOTE. During winter, a possible explanation is that current anthropogenic emission inventories tend to underestimate domestic wood burning in Europe. Residential heating practices are changing in Europe and the use of wood burning has increased considerably in recent years not only in rural but also in urban areas (Szidat et al., 2007) thereby reducing domestic fossil fuel heating. These developments emphasize the need to update current anthropogenic emission inventories for Europe.

- During summer, vegetation fire emissions (van der Werf et al., 2006) are another source of photo-oxidants and aerosols in Europe. Compared with anthropogenic emission data from EMEP, vegetation fires release in particular organic carbon aerosols in considerable amounts (27\% of the total emissions during June 2003), whereas $\mathrm{BC}$ emissions from vegetation fires make up only $2 \%$. Taking into account vegetation fire emissions increased most notably simulated concentrations of OC, but the general underestimation of simulated OC concentration during summer remains unsolved.

- Considerable OC concentrations are determined in the marine boundary layer during summer when POC is released together with sea salt - both in the accumulation mode - dependent on wind speed (O'Dowd et al., 2008). This source of POC has not been taken into account before. It offers however one possible explanation for the missing source of OC in the marine atmosphere, e.g. during the ACE-Asia campaign (Heald et al., 2005), where numerical modelling could not reproduce measured OC concentrations. Transport of marine OC from the ocean to continental areas is found to be relatively small. However coastal areas are affected considerably.

- Gelencser et al. (2007) report a contribution of $78 \%$ from non fossil fuel SOC to the total OC concentration during summer. The dramatic underestimation of simulated organic carbon aerosol concentration during summer is clearly due to a still missing secondary organic aerosol formation module in the REMOTE model extended by the aerosol microphysical module M7 (Vignati et al., 2004).

A comparison of simulation results with the REMOTE model extended by M7 with those obtained with the previously used bulk aerosol mass approach (Marmer and Langmann, 2007) revealed the impact of dry deposition fluxes even though they are small compared with wet deposition fluxes. As dry deposition is a considerable loss process close to the sources before dilution and transport to higher atmospheric levels takes 
place, smaller dry deposition fluxes as determined by REMOTE/M7 are consequently associated with increased longrange transport and higher aerosol burden (about 10\% increase). Modelling of aerosol size distribution and number concentration is not only beneficial for the determination of dry deposition and sedimentation fluxes, but also for estimating e.g. the aerosol impact on human health, the aerosol impact on clouds and precipitation and the principal atmospheric evolution of primary and secondary aerosols from various sources. Future applications of the REMOTE model extended by the aerosol modal microphysics (Vignati et al., 2004) are planned to focus on SOC formation from terrestrial and marine sources, aerosol-cloud interaction studies, coupled ocean-atmosphere biogeochemical modelling and applications over other regions of the Earth.

Acknowledgements. This work has been funded within the EU project MAP and the German Science Foundation Focus Programme Quantitative Precipitation Forecast. The authors would like to thank M. Schulz and L. Ganzeveld for the availability of their Fortran codes.

Edited by: V.-M. Kerminen

\section{References}

Ackermann, I. J., Hass, H., Memmesheimer, M., Ebel, A., Binkowski, F. S., and Shankar, U.: Modal aerosol dynamics model for Europe: Development and first applications, Atmos. Environ., 32, 2981-2999, 1998.

Andersson-Skold, Y. and Simpson, D.: Secondary organic aerosol formation in northern Europe: A model study, J. Geophys. Res., 106, 7357-7374, 2001.

Bauer, S. E., Koch, D., Unger, N., Metzger, S. M., Shindell, D. T., and Streets, D. G.: Nitrate aerosols today and in 2030: a global simulation including aerosols and tropospheric ozone, Atmos. Chem. Phys., 7, 5043-5059, 2007, http://www.atmos-chem-phys.net/7/5043/2007/.

Chang, J. S., Brost, R. A., Isaksen, I. S. A., Madronich, S., Middleton, P., Stockwell, W. R., and Walcek, C. J.: A three-dimensional Eulerian acid deposition model: physical concepts and formulation, J. Geophys. Res., 92, 1481-14700, 1987.

Dusek, U., Frank, G. P., Hildebrandt, L., Curtius, J., Schneider, J., Walter, S., Chand, D., Drewnick, F., Hings, S., Jung, D., Borrmann, S., and Andreae, M. O.: Size matters more than chemistry for the cloud-nucleating ability of aerosol particles, Science, 312, 1375-1378, 2006.

Feichter, J., Kjellstroem, E., Rohde, H., Dentener, F., Lelieveld, J., and Roelofs, G.-J.: Simulation of the tropospheric sulfure cycle in a global climate model, Atmos. Environ., 30, 1693-1707, 1996.

Ganzeveld, L., Lelieveld, J., and Roelofs, G.-J.: Dry deposition parameterization of sulfur oxides in a chemistry and general circulation model, J. Geophys. Res., 103, 5679-5694, 1998.

Geever, M., O’Dowd, C., van Ekeren, S., Flanagan, R., Nilsson, E. D., de Leeuw, G., and Rannik, Ü.: Sub-micron sea-spray fluxes, Geophys. Res. Lett., 32, L15810, doi:10.1029/2005GL023081, 2005.
Gelencser, A., May, B., Simpson, D., Sanchez-Ochoa, A., Kasper-Giebl, A., Puxbaum, H., Caseiro, A., Pio C., and Legrand, M.: Source apportionment of PM2.5 organic aerosol over Europe: primary/secondary, natural/anthropogenic, fossil/biogenic origin, J. Geophys. Res., 112, D23S04, doi:10.1029/2006JD008094, 2007.

Gong, S. L., Barrie, L. A., Blanchet, J. P., von Salzen, K., Lohmann, U., Lesins, G., Spacek, L., Zhang, L. M., Girard, E., Lin, H., Leaitch, R., Leighton, H., Chylek, P., and Huang, P.: Canadian Aerosol Module: A size-segregated simulation of atmospheric aerosol processes for climate and air quality models: 1. Model development, J. Geophys. Res., 108, D4007, doi:10.1029/2001JD002002, 2003.

Grell, G. A., Peckham, S. E., Schmitz, R., McKeen, S. A., Frost, G., Skamarock, W. C., and Eder, B.: Fully coupled "online chemistry" within the WRF model, Atmos. Environ., 39, 6957-6975, 2005.

Guenther, A. B., R. K. Moson and R. Fall: Isoprene and monoterpene emission rate variability: observations with eucalyptus and emission rate algorithm development, J. Geophys. Res., 96, 10 799-10 808, 1991.

Guenther, A. B., Zimmermann, P. R., Harley, P. C., Monson, R. K., and Fall, R.: Isoprene and monoterpene emission rate variability: model evaluations and sensitivity analysis, J. Geophys. Res. 98, 12 609-12 617, 1993.

Haywood, J. and Boucher, O.: Estimates of the direct and indirect radiative forcing due to tropospheric aerosols: A review, Rev. Geophys., 38, 513-543, 2000.

Heald, C. L., Jacob, D. J., Park, R. J., Russell, L. M., Hubert, B. J., Seinfeld, J. H., Liao, H., and Weber, R. J.: A large organic aerosol source in the free troposphere missing from current models, Geophys. Res. Lett., 32, L18809, doi:10.1029/2005GL023831, 2005.

Hodzic, A., Madronich, S., Bohn, B., Massie, S., Menut, L., and Wiedinmeyer, C.: Wildfire particulate matter in Europe during summer 2003: meso-scale modeling of smoke emissions, transport and radiative effects, Atmos. Chem. Phys., 7, 4043-4064, 2007, http://www.atmos-chem-phys.net/7/4043/2007/.

Jacobson, M. Z.: Global direct radiative forcing due to multicomponent anthropogenic and natural aerosols, J. Geophys. Res., 106, 1551-1568, 2001.

Kasper-Giebl, A., Koch, A., Hitzenberger, R., and Puxbaum, H.: Scavenging efficiency of aerosol carbon and sulfate in supercooled clouds at Mt. Sonnblick (3106 m a.s.1, Austria), J. Atmos. Chem., 35, 33-46, 2000.

Koch, D., Schmidt, G. A., and Field, C. V.: Sulfur, sea salt and radionuclide aerosols in GISS Model, J. Geophys. Res., 111, DO6206, doi:10.1029JD005550, 2006.

Langmann, B.: Numerical modelling of regional scale transport and photochemistry directly together with meteorological processes, Atmos. Environ., 34, 3585-3598, 2000.

Langmann, B. and Bauer, S. E.: On the importance of reliable initial and boundary concentrations of ozone for regional scale air pollution modelling, J. Atmos. Chem. 42, 71-90, 2002.

Langmann, B., Bauer, S. E., and Bey, I.: The influence of the global photochemical composition of the troposphere on European summer smog, Part I: Application of a global to mesoscale model chain, J. Geophys. Res., 108(D4), 4146, 
doi:10.1029/2002JD002072, 2003.

Langmann, B.: A model study of the smoke-haze influence on clouds and warm precipitation formation in Indonesia 1997/1998, Atmos. Environ., 41, 6838-6852, doi:10.1016/j.atmosenv.2007.04.050, 2007.

Lauer, A., Hendricks, J., Ackermann, I. J., Schell, B., Hass, H., and Metzger, S.: Simulating aerosol microphysics with the ECHAM/MADE GCM - Part I: Model description and comparison with observations, Atmos. Chem. Phys., 5, 3251-3276, 2005, http://www.atmos-chem-phys.net/5/3251/2005/.

Madronich, S: Photodissociation in the atmosphere. I: Actinic flux and the effect of ground refections and clouds, J. Geophys. Res., 92, 9740-9752, 1987.

Majewski, D.: The Europa Modell of the Deutscher Wetterdienst, Seminar Proceedings ECMWF, 2, 147-191, 1991.

Marmer E. and Langmann, B.: Aerosol modelling over Europe Part I: Inter-annual variability of aerosol distribution, J. Geophys. Res., 112, D23S15, doi:10.1029/2006JD008113, 2007.

Marmer, E., Langmann, B., Hungershöfer, K., and Trautmann, T.: Regional aerosol modelling Part II: Inter-annual variability of aerosol direct radiative forcing over Europe, J. Geophys. Res., 112, D23S16, doi:10.129/2006JD008040, 2007.

Mellor, B. and Yamada, T.: A hierarchy of turbulence closure models for planetary boundary layers, J. Atmos. Sci., 31, 1791-1806, 1974.

Memmesheimer, M., Tippke, J., Ebel, A., Hass, H., Jacobs, H. J., and Laube, M.: On the use of EMEP emission inventories for European scale air pollution modelling with the EURAD model, EMEP Workshop on photooxidant modelling for longrange transport in relation to abatment strategies, Berlin, Germany, 16-19 April 1991, 307-324, 1991.

Mesinger, F. and Arakawa, A.: Numerical methods used in atmospheric models. GARP Public. Ser., 17, 1-64, 1976.

Novakov, T., Cachier, H., Clark, J. S., Gaudichet, A., Macko, S., and Masclet, P.: Characterization of particulate products of biomass combustion, in Sediment Records of Biomass Burning and Global Change, edited by: Clak, J. S., Cachier, H., Goldammer, J. G., and Stocks, B., NATO ASI Series, Springer Verlag, Berlin, Germany, 1997.

O’Dowd, C., Facchini, M. C., Cavalli, F., Ceburnis, D., Mircea, M., Decesari, S., Fuzzi, S., Yoon, Y. J., and Putaud, J. P.: Biogenically-driven organic contribution to marine aerosol, Nature, 432, 7009, doi:10.1038/nature02959, 2004.

O’Dowd, C., Langmann, B., Varghese, S., Scannell, C., Ceburnis, D., and Facchini, M. C.: A combined organic-inorganic sea-spray source function, Geophys. Res. Lett., 35, L01801, doi:10.1029/2007GL030331, 2008.

Roeckner, E., Arpe, K., Bengtsson, L., Christoph, M., Claussen, M., Dümenil, L., Esch, M., Giorgetta, M., Schlese, U., and Schulzweida, U.: The atmospheric general circulation model ECHAM-4: Model description and simulation of present-day climate, MPI-Report No. 218, Max Planck Institute for Meteorology, Hamburg, Germany, 1996.

Seinfeld, J. H. and Pandis, S. N.: Atmospheric chemistry and physics: from air pollution to climate change, WileyInterscience, 1998.

Simpson, D., Winiwarter, W., Boerjesson, G., Cinderby, S., Ferreiro, A. Guenther, A., Hewitt, C. N., Janson, R., Khalil, M. A. K., Owen, S., Pierce, T. E., Puxbaum, H., Shearer, M., Skiba,
U., Steinbrecher, R., Tarrason L., and Oequist, M. G.: Inventorying emissions from nature in Europe, J. Geophys. Res., 104, 8113-8152, 1999.

Smolarkiewitz, P. K.: A simple positive definite advection scheme with small implicit diffusion, Mon. Weather Rev., 111, 479-486, 1983.

Solmon, F., Giorgi F., and Liousse, C.: Aerosol modelling for regional climate studies: application to anthropogenic particles and evaluation over a European/African domain, Tellus, 58B, 51-72, 2006.

Stier, P., Feichter, J., Kinne, S., Kloster, S., Vignati, E., Wilson, J., Ganzeveld, L., Tegen, I., Werner, M., Balkanski, Y., Schulz, M., Boucher, O., Minikin, A., and Petzold, A.: The aerosolclimate model ECHAM5-HAM, Atmos. Chem. Phys., 5, 11251156, 2005,

http://www.atmos-chem-phys.net/5/1125/2005/.

Stockwell, W. R., Middleton, P., Chang, J. S., and Tang, X.: The second generation regional acid deposition model: chemical mechanism for regional air quality modelling, J. Geophys. Res., 95, 16343-16367, 1990.

Stoddart, J., Jeffries, D., Lkewolle, A., Clair, T., Dillon, P., Driscoll, C., Fortius, M., Johannsessen, M., Kahl, J., Kellogg, J., Kemp., A., Mannio, J., Montheith, D., Murdoch, P., Patrick, S., Rebsdorf, A., and Skjelkv, B.: Regional trends in aquatic recovery from acidification in North America and Europe, Nature, 401, 575-578, 1999.

Szidat, S., Prevot, A. S. H., Sandradewi, J., Alfarra, M. R., Synal, H.-A., Wacker, L., and Baltenschlager, U.: Dominant impact of residential wood burning on particulate matter in Alpine valleys during winter, Geophys. Res. Lett., 34, L05820, doi:10.1029/2006GL028325, 2007.

Tiedtke, M.: A comprehensive mass flux scheme for cumulus parameterisation in large-scale models, Mon. Weather Rev., 117, 1778-1800, 1989.

Tsyro, S., Simpson, D., Tarrason, L., Klimont, Z., Kupiainen, K., Pio C., and Yttri, K. E.: Modelling of elemental carbon over Europe, J. Geophys. Res., 112, D23S19, doi:10.1029/2006JD008164, 2007.

Van der Werf, G. R., Randerson, J. T., Giglio, L., Collatz, G. J., Kasibhatla, P. S., and Arellano Jr., A. F.: Interannual variability in global biomass burning emissions from 1997 to 2004, Atmos. Chem. Phys., 6, 3423-3441, 2006,

http://www.atmos-chem-phys.net/6/3423/2006/.

Vignati, E., Wilson, J., and Stier, P.: M7: An efficient size-resolved aerosol microphysics module for large-scale aerosol transport models, J. Geophys. Res., 109, D22202, doi:10.1029/2003JD004485, 2004.

WHO: World Health Report 2002, Tech. Rep., World Health Organisation, Genova 2002.

Walcek, C. J. and Taylor, G. R.: A theoretical method for computing vertical distributions of acidity and sulfate production within cumulus clouds, J. Atmos. Sci., 43, 339-355, 1986.

Walcek, C. J., Brost, R. A., Chang, J. S., and Wesley, M. L.: $\mathrm{SO}_{2}$, Sulfate and $\mathrm{HNO}_{3}$ deposition velocities computed using regional landuse and meteorological data, Atmos. Environ., 20, 946-964, 1986.

Wesley, M. L.: Parameterization of surface resistances to gaseous dry deposition in regional-sclae numerical models, Atmos. Environ., 23, 1293-1304, 1989. 
Yoon, Y. J., Ceburnis, D., Cavalli, F., Jourdan, O., Putaud, J. P., Facchini, M. C., Decesari, S., Fuzzi, S., Jennings, S. G., and O'Dowd, C.: Seasonal characteristics of the physico-chemical properties of North Atlantc marine aerosols, J. Geophys. Res., 112, D04206, doi:10.1029/2005JD007044, 2007.

Yttri, K. E., Aas, W., Bjerke, A., Ceburnis, D., Dye, C., Emblico, L., Facchini, M. C., Forster, C., Hanssen, J. E., Hannsson, H. C., Jennings, S. G., Maenhaut, W., Putaud, J. P., and Torseth, K.: Elemental and organic carbon in PM10: A one year measurement campaign within the European Monitoring and Evaluations Programme EMEP, Atmos. Chem. Phys., 7, 5711-5725, 2007,

http://www.atmos-chem-phys.net/7/5711/2007/.
Zhang, Y., Seigneur, C., Seinfeld, J. H., Jacobson, M. Z., and Binkowsky, F. S.: Simulation of aerosol dynamics: A comparative review of algorithms used in air quality models, Aerosol Sci. Technol., 31, 487-514, 1999. 